Clóvis Cavalcanti, economista (Universidade

Federal de Pernambuco - UFPel, possui cursos de aperfeiçoamento pela Escola de Pós-

Graduação em economia da Dundação Getúlio

Vargas - FGV, Rio de Janeiro. Mestre em economia (Universidade de Yale), é

superintendente do Instituto de Pesquisas

Sociais da Fundação Joaquim Nabuco.

\title{
Emprego e renda no setor informal: o caso de Fortaleza
}

\section{Introdução}

Quem são as pessoas que trabalham no setor informal, quais suas motivações e qual o escalão e perfil da condição sócio-econômica em que estão colocadas? Qual a relação dos trabalhadores informais e suas famílias com a pobreza urbana de um centro metropolitano que atrai migrantes e não se revela pródigo no oferecimento de meios para uma sobrevivência firme de inúmeros de seus residentes? Perguntas desse jaez incitam a curiosidade de quem se debruça sobre o setor informal, desejando compreender de que maneira ele se presta para solucionar problemas de emprego e renda, evitando sobretudo maiores sacríficios para a população que não se beneficia do processo de crescimento do produto por habitante que tem lugar no país. Essa população de não-beneficiários presumíveis constitui precisamente o objeto de análise do presente artigo ${ }^{1}$ que, apoiando-se em dados coletados durante pesquisa de campo na capital do Ceará em julho-agosto de 1978 - tomando junho do mesmo ano como período de referência - , examina traços demográficos, sócio-econômicos e relativos às ocupações da população em epígrafe.

Antes de proceder ao relato e interpretação do material colhido junto ao efetivo humano de mais baixa posição social de Fortaleza, convém deixar claro certas categorias e formas de tratamento adotadas. Primeiramente, qual o espaço geográfico do estudo? Pensou-se, de início, em cobrir, de maneira literal, a área definida pela Região Metropolitana de Fortaleza (RMF), que é integrada pelos municípios de Aquiraz, Caucaia, Fortaleza, Maranguape e Pa- catuba. Todavia, como do ponto de vista demográfico Fortaleza representava 82,7\% da RMF em 1970 , uma razão que teria subido para $87,3 \%$ de 19782 , foi tomada a decisão - por motivos também orçamentárias e ligadas às grandes distâncias que teriam de ser percorridas na realização de entrevistas - de concentrar-se o levantamento exclusivamente no município da capital do Ceará. Os resultados conseguidos não deverão diferir, assim, do panorama relativo à RMF, muito embora, no caso dessa última, ainda seja algo saliente a presença de populações rurais.

Outra providência necessariamente adotada reporta-se à própria demarcação do estrato populacional alvo da pesquisa. Ou seja, desejando-se estudar a oferta de mão-de-obra ao setor informal, cumpria ter acesso apenas às pessoas que realizam, como meio de vida, atividades informais. Contudo, onde estariam essas pessoas? Enfrentou-se aqui, por conseguinte, impasse análogo ao verificado em pesquisa em Salvador ${ }^{3}$ - que, com a de Fortaleza, compõe um mesmo maço, um mesmo marco de análise. Para ter acesso às pessoas que trabalham no setor não-organizado da economia, a melhor rota seria procurando-as nas microempresas informais. $\mathrm{O}$ impasse, ainda assim, continua, uma vez que o universo dos pequenos negócios cerca-se de semelhante indeterminação, sem cadastros, sem registros, sem mapas de localização. A solução foi seguir o mesmo expediente posto em prática em Salvador. a saber: identificar a mão-de-obra informal através dos espaços urbanos de Fortaleza onde se abriga a população de baixa renda. ${ }^{4} \dot{E}$ certo que nesses espaços se misturam trabalhadores formais e trabalha- 
dores informais, do mesmo modo que nos ambientes urbanos afluentes vão se encontrar moradores ligados à economia informal. No entanto, tais equívocos podem ser considerados de grandeza de segunda ordem. Problema maior surgiu quando, pesquisando-se as áreas de baixa renda, onde reside a força de trabalho informal, muitas vezes não se tem acesso ao trabalhador, mas a alguém do domicílio que pode dar as informações buscadas, um meio claramente deficiente de se chegar ao fim colimado. Por outro lado, não se restringiu o levantamento unicamente às famílias cujos membros pertencessem apenas ao setor informal. Feita a seleção da amostra, sorteados os domicílios, empreendiamse as entrevistas, deixando-se de lado apenas os casos onde houvesse rejeição aos entrevistadores. Desse modo, o que o levantamento proporciona é uma visão compreensiva do quadro familiar, econômico e de emprego na população pobre como um todo de Fortaleza.

Exatamente a amplitude dessa população, qual seu peso relativo no efetivo demográfico fortalezense, não é possível precisar com rigor maior à base tão-só dos dados obtidos a seu respeito.

O material do presente artigo permite na segunda seção, abaixo, desenhar o perfil de características demográficas da população estudada, e na terceira seção, determinar o nível sócio-econômico dessa mesma população; na quarta, é possível indicar a natureza do mercado de trabalho onde as pessoas exercem suas ocupações.

Vale assinalar que o presente artigo, dada a disponibilidade de informações, utiliza o caso de Salvador como termo de comparação. Todavia, evita repetir enfoques e abordagens adotados no estudo da capital baiana, antes guiando-se por um sentido de complementação que procura oferecer esclarecimentos adicionais ou vislumbrar aspectos novos não trazidos à baila naquele estudo. É evidente que existem aqui pontos de natureza repetitiva, caminhos paralelos, passagens já contemplados, convergências de comentários, muitas vezes podendo até sugerir a impressão de cópia. Entretanto, isso resulta da impossibilidade de uma total originalidade em matéria que, sobre ser versada pelo mesmo autor, está embebida de idênticos condicionamentos e matrizes definidoras no seu contexto real.

\section{Retrato demográfico da população de baixa renda de Fortaleza}

De uma amostra de 800 unidades domiciliares, foram aproveitadas na pesquisa 777 entrevistas, número que deve corresponder a cerca de $0,5 \%$ da população de baixa renda de Fortaleza em 1978.5 Conforme já se mencionou, as entrevistas tiveram lugar nos distritos de menor poder aquisitivo do município fortalezense, cobrindo uma população de 4.210 pessoas, cuja estrutura etária se expõe no quadro 1. Trata-se, como se vê de pronto na tabela, de um contingente conspicuamente jovem, com $58,2 \%$ dos indivíduos formando no grupo de menos de 20 anos de idade uma proporção que no total da RMF, em 1970, de acordo também com o quadro 1, atingia $53,8 \%$ e, na populacão de baixa renda de Salvador, em 1978, era de 55,7\%.6 Há, pois, no caso dos habitantes de condição econômica mais modesta de Fortaleza, forte assimetria da faixa de idades inferiores relativamente às demais, situação cujos reflexos sobre o esforço de provimento da subsistência familiar e sobre a estrutura de ocupações desempenhadas possuem óbvias repercussões. Noutras palavras, haverá um peso, um encargo maior sobre os ombros das pessoas adultas na população estudada, devendo registrar-se também a presença de formas de emprego mais frouxas como meio de reforço de orçamentos domésticos insuficientes. Pelos dados do quadro 1, aparentemente, o efetivo humano de baixa renda de Fortaleza constitui um conjunto demograficamente distinto da população total da cidade, resultado esperado, sobretudo quando aponta o primeiro como caracteristicamente mais jovem do que a última.

\section{Quadro 1}

Fortaleza - Número de pessoas, por sexo e idade, da população de baixa renda pesquisada - junho/1978

\begin{tabular}{|c|c|c|c|c|c|c|c|}
\hline \multirow{2}{*}{$\begin{array}{l}\text { Idade } \\
\text { (anos) }\end{array}$} & \multicolumn{3}{|c|}{ Dados absolutos (pessoas) } & \multicolumn{3}{|c|}{ Dados relativos $(\%)$} & \multirow{2}{*}{$\begin{array}{c}\text { Total da } \\
\text { RMF }(\%) \\
1970 \\
\end{array}$} \\
\hline & Homens & Mulheres & Total & Homens & Mulheres & Total & \\
\hline $\begin{array}{l}0-4 \\
5-9 \\
10-14 \\
15-19 \\
20-24 \\
25-29 \\
30-39 \\
40-49 \\
50-69 \\
70 \text { e mais } \\
\text { Total } \\
\end{array}$ & $\begin{array}{r}361 \\
358 \\
314 \\
226 \\
151 \\
140 \\
223 \\
176 \\
129 \\
20 \\
2.098 \\
\end{array}$ & $\begin{array}{r}334 \\
353 \\
297 \\
207 \\
170 \\
141 \\
258 \\
181 \\
143 \\
28 \\
2.112 \\
\end{array}$ & $\begin{array}{r}695 \\
711 \\
611 \\
433 \\
321 \\
279 \\
483 \\
357 \\
272 \\
48 \\
4.210 \\
\end{array}$ & $\begin{array}{r}17,2 \\
17,1 \\
15,0 \\
10,8 \\
7,2 \\
6.7 \\
10,6 \\
8,4 \\
6.1 \\
1,0 \\
100,0\end{array}$ & $\begin{array}{r}15,8 \\
16,7 \\
14,1 \\
9,8 \\
8,0 \\
6,7 \\
12,2 \\
8,6 \\
6,8 \\
1,3 \\
100,0\end{array}$ & $\begin{array}{r}16,5 \\
16,9 \\
14,5 \\
10,3 \\
7,6 \\
6,7 \\
11,5 \\
8,5 \\
6,5 \\
1,1 \\
100,0\end{array}$ & $\begin{array}{r}16,7 \\
14,1 \\
11,7 \\
11,3 \\
10,0 \\
7,2 \\
11,3 \\
8,2 \\
7.7 \\
1,8 \\
100,0 \\
\end{array}$ \\
\hline
\end{tabular}

Por domicílio investigado, encontrou-se uma média de 1,54 pessoa economicamente ativa - ou, mais precisamente, 1.198 integrantes da força de trabalho entre as 777 famílias da amostra. A cifra equivale a uma fração da população economicamente ativa (PEA) sobre o total demográfico - denominada também de taxa de participação - de $28,4 \%$, correspodendo a 3,5 pessoas inativas por cada uma que trabalha. Na RMF como um todo, a relação era praticamente idêntica em 1970 - com uma taxa de participação de $28,5 \%$ - , de acordo com o censo de então. Todavia, no estudo de Salvador obtevese uma taxa de participação bem mais alta, da or- 
dem de $36,6 \%, 7$ resultado que pode significar, no caso de Fortaleza, a existência de oportunidades de emprego mais escassas, além de sugerir uma situação econômica desfavorável para o domicílio fortalezense de poucas posses, com número limitado de integrantes da força de trabalho tendo que prover o sustento de maior fatia de dependentes - conclusão, aliás, em sintonia com o grande peso das pessoas de menor idade na população da pesquisa, antes sublinhado. Deve-se lembrar que as amostras de Fortaleza e Salvador, sem possuir os mesmos contornos - afinal, a referência para delimitação dos universos, em ambos os casos, foi o espaço territorial - , não serão formadas da mesma matéria. Contudo, a diferença de proporções é elevada, comunicando sem dúvida uma mensagem que acusaria maior desconforto sócio-econômico da população de baixa renda de Fortaleza.

A mão-de-obra informal na PEA dessa população - formada por 490 pessoas, na amostra comparece com uma taxa de 40,9\%. Deve-se sublinhar, contudo, a imprecisão dessa cifra, cujo valor resulta da soma do número de trabalhadores incluídos nas categorias ocupacionais de autonômo informal, auxiliar não remunerado da família, ambulante e aprendiz, sem nenhum caso de inclusão de trabaIhador empregado. Ora, o fato de um indivíduo declarar-se empregado não o exclui do setor informal, uma vez que o emprego pode se dar em unidade de produção não-organizada. Fica difícil, todavia, detectar a natureza do emprego de uma pessoa por meio de rápidas entrevistas - que nem sempre se realizam diretamente com o interessado. Assim, a proporção correspondente à PEA informal será superior aos $40,9 \%$ registrados, os quais, de qualquer maneira, indicam uma fatia maior de ocupações informais em Fortaleza do que em Salvador, onde é de $37,6 \%$ o número de indivíduos que integram, na PEA de baixa renda, a mão-de-obra informal definida como no início deste parágrafo. ${ }^{8}$ Talvez a comparação com Salvador não seja tão elucidativa, dada a pequena diferença que separa 40,9 de 37,6\%, e considerando a divergência dos universos. Sem embargo, o que é marcante, tanto em uma como na outra capital nordestina, é o fato de que há um contingente apreciável de pessoas nos grupos populacionais de menores remunerações, que está ligado ao mercado informal de emprego e dele deve depender para o atendimento das necessidades basilares de consumo. Essa impressão se extrai do contacto com as famílias pesquisadas, diante de suas modestas e, não raro, modestíssimas habitações; diante de cenas testemunhadas durante a pesquisa, ciasalizando a vida das famílias, inclusive providências relativas à alimentação etc. Muitas vezes, os pesquisadores presenciaram momentos difíceis vividos pela população, como o fato de estar-se em um lar com crianças, perto do meio-dia, sem qualquer comida em preparo na panela.

Individualmente, conforme explicita o quadro 2 , as ocupações enfeixadas sob a legenda de empregado $(44,8 \%$ da mão-de-obra da população pesquisada) constituem a principal fonte de trabalho das pessoas ativas em Fortaleza. É impossível identificar quantos, entre os empregados, prestam serviços ao setor informal, de modo que, segundo quadro 2 , as

$$
\begin{aligned}
& \text { Quadro } 2 \\
& \text { Fortaleza - Estrutura do emprego da população } \\
& \text { pesquisada, por sexo - junho/1978 }
\end{aligned}
$$

\begin{tabular}{|c|c|c|c|}
\hline \multirow{2}{*}{ Posição na ocupação } & \multicolumn{3}{|c|}{ Sexo } \\
\hline & Masculino & Feminino & Total \\
\hline 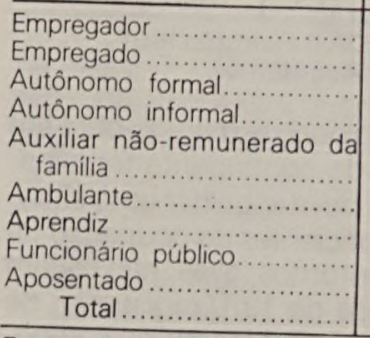 & \begin{tabular}{r|}
0,5 \\
51,7 \\
0,8 \\
32,4 \\
\\
2,1 \\
0,1 \\
3,2 \\
9,5 \\
100,0 \\
\end{tabular} & \begin{tabular}{|r|}
28,5 \\
0,3 \\
55,0 \\
- \\
0,6 \\
0,6 \\
2,0 \\
13,1 \\
100,0 \\
\end{tabular} & $\begin{array}{r}0,3 \\
44,8 \\
0,7 \\
38,9 \\
- \\
1,7 \\
0,3 \\
2,8 \\
10,5 \\
100,0 \\
\end{array}$ \\
\hline
\end{tabular}
(porcentagens)

Fonte: Pesquisa direta da FUNDAJ

ocupações informais indiscutiveis se resumem a autônomo informal (38,9\% da mão-de-obra), ambulante $(1,7 \%)$ e aprendiz $(0,3 \%)$, não havendo sido acusada a situação de auxiliar não remunerado da família, a qual, em Salvador, congrega $0,6 \%$ da forca de trabalho de baixa renda. ${ }^{9} \mathrm{Há}$ ainda, segundo o quadro 2, um número acentuado de aposentados no contingente da pesquisa $(10,5 \%)$, em proporção bem acima da constatada em Salvador $(6,1 \%) .10 \mathrm{~A}$ presença do setor informal, por outro lado, tende a ser mais intensa entre a mão-de-obra feminina do que entre os homens, como se depreende do quadro 2, denotando a fragilidade do emprego das muIheres e o papel subsidiário que as atividades informais parecem assumir no panorama doméstico da população pobre. Nessa mesma população, basicamente, a estrutura do emprego é constituída do trabalho dos empregados e das ocupações informais, numa razão de proporcionalidade, quiçá, de 1 para 1 , sendo de quase 1 para 2 no caso de mão-de-obra feminina - um trabalhor formal para cada 2 informais - e de 1,5 para 1, no caso de mão-de-obra masculina. Ou seja, os homens vão menos para o setor informal que as mulheres; estas no entanto, representando apenas $41,2 \%$ do total da força de trabalho informal no contingente trabalhador pobre de Fortaleza, conforme indica o quadro 3 , contra os $51,2 \%$ que lhes cabem em Salvador. ${ }^{11}$ Na verdade, revela-se pequeno o comparecimento de mulheres 


\section{Quadro 3}

Fortaleza - Divisão da PEA pesquisada, por sexo e por posição na ocupação junho/1978 (porcentagens)

\begin{tabular}{|c|c|c|c|}
\hline \multirow{2}{*}{ Posição na ocupação } & \multicolumn{3}{|c|}{ Sexo } \\
\hline & Masculino & Feminino & Total \\
\hline 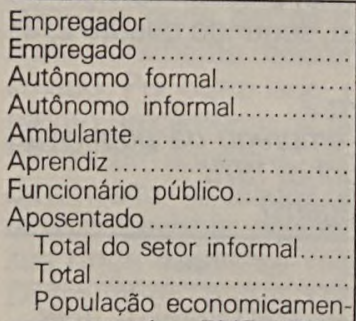 & $\begin{array}{r}100,0 \\
81,4 \\
87,5 \\
58,7 \\
90,0 \\
33,3 \\
79,4 \\
63,5 \\
58,8 \\
70,6\end{array}$ & \begin{tabular}{l|}
$\overline{18,6}$ \\
12,5 \\
41,3 \\
10,0 \\
66,7 \\
20,6 \\
36,5 \\
41,2 \\
29,3
\end{tabular} & $\begin{array}{l}100,0 \\
100,0 \\
100,0 \\
100,0 \\
100,0 \\
100,0 \\
100,0 \\
100,0 \\
100,0 \\
100,0\end{array}$ \\
\hline mente ativa, RMF, 1970 & 71,3 & 28,7 & 100,0 \\
\hline
\end{tabular}

Fontes: Pesquisa direta da FUNDAJ; Fundação IBGE, Censo Demográfico - Ceará (1970).

para a formação da oferta global de mão-de-obra em Fortaleza lapenas $29,3 \%$ do contingente trabalhador investigado), fato que deve espelhar uma situação de oportunidades insuficientes de ocupação na capital cearense, cujos contornos, aliás, não seriam diferentes dos que o censo de 1970 registrava, de conformidade com o quadro 3. Mesmo na categoria de autônomo informal, a preponderância do efetivo masculino mostrada pela última tabela é peremptória, contrastando novamente com o perfil observado em Salvador, onde com maior relevo aparece o trabalho do sexo oposto.

As mulheres em Fortaleza, por outro lado, estariam concentradas em ocupacões que pertencem à prestação de serviços de um modo bem mais evidente que os homens (ver quadro 4), um fenômeno que comumente se associa às vezes em que o setor informal aparece com destaque na economia. ${ }^{12}$ Tanto a força de trabalho feminina como a masculina, porém, dependem basicamente da ocupação terciária, havendo apenas entre os homens, diferentemente das mulheres, grande parcela de trabalhadores englobados pelo setor de construção. É pequena a ligação com a indústria e inexpressiva com os demais setores de produção. Isto dá bem uma idéia da natureza do trabalho da população de baixa renda, que não é, saliente-se, específica de Fortaleza. Ademais, comprovando-se que na capital do Ceará, onde o setor informal tem mais peso que em Salvador, o emprego nos serviços (exclusive comércio, transporte e setor público) aparece com destaque superior à capital baiana $145,4 \%$ do emprego em Salvador ${ }^{13}$, contra $49,8 \%$ em Fortaleza), pode-se concluir que atividades informais e ocupações terciárias são categorias estreitamente relacionadas. A conclusão é enfatizada ao comparar-se o emprego masculino com o feminino, uma vez que no domínio do último se combinam mais ocupacões terciárias com peso mais elevado do setor informal na PEA respectiva.

\section{Quadro 4}

Fortaleza: setor de ocupação das pessoas economicamente ativas, por sexo, na população pesquisada - junho/1978

(porcentagens)

\begin{tabular}{|c|c|c|c|}
\hline \multirow{2}{*}{ Setor de ocupação } & \multicolumn{3}{|c|}{ Sexo } \\
\hline & Masculino & Feminino & Total \\
\hline 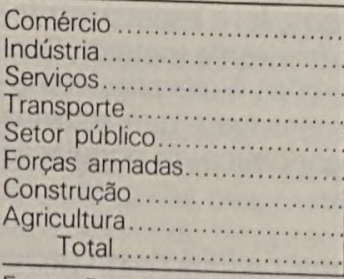 & \begin{tabular}{r|}
15,0 \\
13,9 \\
43,7 \\
2,9 \\
4,1 \\
0,5 \\
19,8 \\
0,1 \\
100,0 \\
\end{tabular} & \begin{tabular}{r|}
15,2 \\
15,8 \\
64,6 \\
0,3 \\
2,8 \\
$\overline{0,9}$ \\
0,3 \\
100,0 \\
\end{tabular} & $\begin{array}{r}15,1 \\
14,4 \\
49,8 \\
2,2 \\
3,7 \\
0,4 \\
14,3 \\
0,2 \\
100,0 \\
\end{array}$ \\
\hline
\end{tabular}

Fonte: Pesquisa direta da FUNDAJ.

Do mesmo modo que em Salvador, o efetivo populacional que trabalha nas atividades informais de Fortaleza apresenta-se, na média, mais idoso que a PEA total. Enquanto, segundo os dados da pesquisa, o primeiro contingente apresenta a idade me diana de 37,3 anos, o último mostra-se com 32,8 anos. Por outro lado, nas faixas etárias abaixo de 30 anos (ver o quadro 5) há relativamente mais pessoas na PEA total $(36,9 \%)$ do que na informal $(32,7 \%)$, a qual funcionaria, assim, como refúgio da mão-deobra menos jovem. Na verdade, presença feminina, importância dos serviços e peso das pessoas de mais idade são atributos do mercado informal de emprego que, tanto em Fortaleza como em Salvador, mostram o papel ancilar desempenhado por esse segmento da atividade econômica. 0 quadro 6 reafirma a evidência revelada pelo quadro 5 , indicando que a ocupação de autônomo informal cresce de importância acima dos 30 anos de idade, e que a de

\section{Quadro 5}

Fortaleza - Estrutura etária da população economicamente ativa pesquisada - junho/1978 (porcentagens)

\begin{tabular}{|c|c|c|}
\hline Idades (anos) & $\begin{array}{l}\text { PEA } \\
\text { total } \\
\end{array}$ & $\begin{array}{c}\text { PEA } \\
\text { informal }\end{array}$ \\
\hline 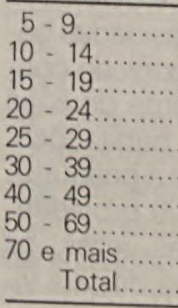 & $\begin{array}{r}0,1 \\
1,8 \\
8,9 \\
12,9 \\
13,2 \\
24,9 \\
19,8 \\
15,4 \\
3,0 \\
100,0 \\
\end{array}$ & $\begin{array}{r}2,2 \\
8,2 \\
10,6 \\
11,6 \\
29,4 \\
22,6 \\
14,7 \\
0,6 \\
100,00 \\
\end{array}$ \\
\hline
\end{tabular}

Fonte: Pesquisa direta da FUNDAJ. 


\section{Quadro 6}

Fortaleza - Distribuição da posição na ocupação da PEA na população pesquisada, por idade - junho/1978 (porcentagens)

\begin{tabular}{|c|c|c|c|c|c|c|c|c|c|}
\hline \multirow[b]{2}{*}{ Idades (anos) } & \multicolumn{9}{|c|}{ Posição na ocupação } \\
\hline & Empregador & Empregado & $\begin{array}{c}\text { Autônomo } \\
\text { formal }\end{array}$ & $\begin{array}{c}\text { Autônomo } \\
\text { informal }\end{array}$ & Ambulante & Aprendiz & $\begin{array}{c}\text { Funcionário } \\
\text { público }\end{array}$ & Aposentado & Total \\
\hline $\begin{array}{c}5-9 \\
10-14 \\
15-19 \\
20-24 \\
25-29 \\
30-39 \\
40-49 \\
50-69 \\
70-\text { e mais } \\
\text { Total }\end{array}$ & $\begin{array}{l}\overline{-} \\
\overline{-} \\
\overline{0,6} \\
\overline{0} \\
0,3 \\
0,8 \\
\overline{2,8} \\
0,3\end{array}$ & $\begin{array}{r}100,0 \\
50,0 \\
59,8 \\
62,6 \\
60,1 \\
43,6 \\
39,2 \\
23,9 \\
\overline{44,7}\end{array}$ & $\begin{array}{l}- \\
- \\
1,9 \\
- \\
\overline{0} \\
0,7 \\
0,8 \\
1,1 \\
8,3 \\
0,7\end{array}$ & $\begin{array}{l}-\overline{22,7} \\
34,6 \\
32,9 \\
33,5 \\
47,0 \\
46,0 \\
37,5 \\
\overline{-} \\
39,0\end{array}$ & $\begin{array}{r}-\overline{27,3} \\
1,9 \\
0,7 \\
1,9 \\
1,3 \\
0,8 \\
1,1 \\
\overline{1,7}\end{array}$ & $\begin{array}{l}- \\
\overline{-} \\
0,9 \\
\overline{0,6} \\
\overline{-} \\
\overline{0,5} \\
\overline{0} \\
0,3\end{array}$ & $\begin{array}{l}- \\
- \\
0,9 \\
2,6 \\
1,3 \\
4,1 \\
3,8 \\
3,3 \\
- \\
2,8\end{array}$ & $\begin{array}{l}- \\
\overline{-} \\
\overline{0} \\
0,6 \\
2,5 \\
3,0 \\
8,5 \\
32,6 \\
88,9 \\
10,5\end{array}$ & $\begin{array}{l}100,0 \\
100,0 \\
100,0 \\
100,0 \\
100,0 \\
100,0 \\
100,0 \\
100,0 \\
100,0 \\
100,0\end{array}$ \\
\hline
\end{tabular}

Fonte: Pesquisa direta da FUNDAJ.

empregado é hegemônica abaixo da mesma referência etária. O resultado não chega a ser totalmente conclusivo, porém, em virtude das imprecisões definicionais relativas à PEA total e informal. No entanto, a tendência registrada no tocante à categoria de autônomo informal (quadro 6) parece suficientemente significativa como sintoma de uma força de trabalho mais velha empenhada em pequenos negócios, em biscates e em serviços com pouca organização.

Outra característica demográfica dos trabalhadores informais de Fortaleza é sua precedência que, como revela o quadro 7 , localiza-se marcantemente fora da RMF. Com efeito, menos de $1 / 3$ dessa força de trabalho é natural dos cinco municípios integrantes da área metropolitana, um número que, no caso de Salvador e da respectiva região metropolitana, ultrapassava dos $2 / 5(42,2 \%) .14$ A capital do Ceará funciona, portanto, como intenso foco de atração de migrantes, que para aí vão diretamente de seus pontos de origem lé o que sugere o número de migrações anotado no quadro 7) e, atingindo a idade de trabalhar, abrigam-se em empregos informais. Na realidade, mais da metade dos trabalhadores do setor informal que são migrantes já chegou a Fortaleza nas faixas etárias ativas, como retrata o quadro 7, premida pela busca de melhores condições de vida $(41,6 \%$ dos casos) ou pela falta de emprego no local onde vivia $(11,2 \%)$. Aparentemente, esse desejo de conquistar um padrão mais decente de vida não terá sido de todo alcançado, como se pode demonstrar atentando-se para a elevada proporção de migrantes na força de trabalho informal e para a presença de uma proporção alta de pessoas mais veIhas nessa mesma mão-de-obra. Ou seja, os migrantes ingressam no setor informal talvez imaginando engajar-se mais tarde numa ocupação mais moderna, mas aí terminam ficando, por falta de opções.

Na verdade, o elevado percentual de pessoas

\section{Quadro 7}

Fortaleza - Local de nascimento dos integrantes do setor informal e dados referentes àqueles que migraram - junho/1978.

A. Local de nascimento $\%$

RMF ........................................ 30,9

Zona rural, Ceará ..................................... 11,5

Cidade, Ceará.......................................... 48,8

Outro estado .......................................... 8,8

Năo sabe..........................................

Total ......................................... 100,0

B. Idade de chegada à RMF (anos) $\%$

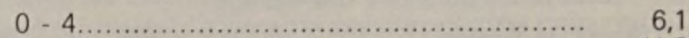

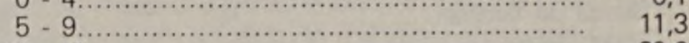

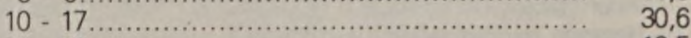

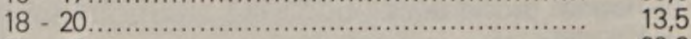

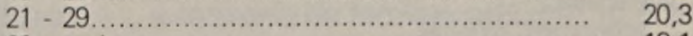

30 e mais............................................... 18,1

Total ........................................ 100,0

C. Número de migraçōes $\quad \%$

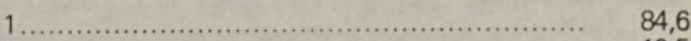

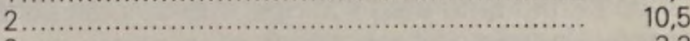

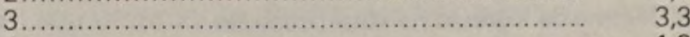

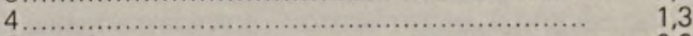

5 e mais ......................................... 0,3

Total ........................................ 100,0

D. Razões da migração $\quad \%$

Companhia dos pais.............................. $\quad 37,7$

Atração pelo grande centro.......................... 2,6

Para melhorar educação ............................ 1,6

Doença ...........................................

Falta de emprego onde vivia...................... 11,2

Melhoria das condiçőes de vida....................... 41,6

Melhoria de salário ................................. $\quad 3,0$

Seca ............................................. 2,

Total ........................................ 100,0

Fonte: Pesquisa direta da FUNDAJ.

que, no grupo pesquisado, já experimentou o desemprego $(56,9 \%$ dos indivíduos, conforme estampa o quadro 8) atesta a existência de asperezas no 
mercado de trabalho de Fortaleza, ainda que seja curto o prazo que normalmente o indivíduo permanece desempregado. Não se deve esquecer, entretanto, que, para uma pessoa de baixa renda - como sói acontecer com as da população enfocada ficar sem trabalho representa luxo insustentável. Tanto é que, como o próprio quadro 8 patenteia, a sobrevivência dos desempregados é proporcionada por ajuda da família - família pobre, como se sabe - ou pela realização de biscates. Isso, aliás, é mais um lastro para o entendimento das dificuldades de vida de uma população que, numa cidade moderna do Nordeste, sobrevive graças às possibilidades ofe-

\section{Quadro 8}

Fortaleza - Caracterização do desemprego e da obtenção da primeira ocupação da PEA na população pesquisada - junho/1978.

\section{(porcentagens)}

1. Experimentaram ou não o desemprego

Sim.

Não .

Não se aplica

Total.

56,9

38,9

4,2

100,0

2. Duração do desemprego (meses)

Menos de 5 .

5 a 8.

$\%$

9 a 12

60,1

20,1

Mais de 12

Total...

16,6

100,0

3. Sobrevivência durante o desemprego

Ajuda da família

Indenizacão..........

Heranca ou donativos.

Biscates

Economias próprias

Ajuda de amigos.

INPS

Esmola

Outras formas

Total

65,9

0,8

0,4

19,5

6,5

3,3

2,0

1,6

100,0

4. Forma de ingresso na atual ocupação

Por meio de amigos.

Por meio de familiares

Iniciativa própria

Trabalha com a familia

Convite do empregador

Agência de emprego

Teste, concurso

Outra..

Total

5. Dificuldades para obtenção do primeiro emprego

Não teve

Falta de documentos.

Falta de qualificação

Grande concorrência

Mercado de trabalho saturado

Outra.

Total ............................

6,4

11,0

100,0

Fonte: Pesquisa direta da FUNDAJ

recidas pelo setor informal. Suportando o desempre go mercê da ajuda da família, as pessoas ingressam também em suas ocupações, como está indicado no quadro 8 , basicamente por intermédio de amigos $(37,0 \%$ dos casos) ou de familiares $(18,9 \%)$, com minimo recrutamento mediante veículos formais de admiss̃ão (agência de emprego, teste, concurso) Talvez por isso seja plausível a informacão do mesmo quadro 8 de que $51,7 \%$ dos trabalhadores cobertos pelo estudo não enfrentaram dificuldades na obtenção de seu primeiro emprego: é que o emprego resultou da intermediação de parentes ou amigos, uma forma óbvia de minimizar atritos e resistências na superação das incertezas do mercado ocupacional. Por outro lado, durante o desemprego, o fato de muito pouco ou quase nenhum relevo ser reservado a saidas ou soluções via setor informal, para a emergência, de acordo com os resultados mostrados no quadro 8 , caracteriza uma significação mais duradoura e menos emergencial do mesmo setor. No fundo, verdadeiramente, o que isso quereria atestar é a natureza mais profunda, estrutural, e não conjuntural, epidérmica, do problema de emprego em Fortaleza.

\section{Condição econômica da população de baixa renda de Fortaleza}

Aparentemente e à primeira vista, não se mostra fácil a tarefa de conciliar as informações do quadro 9 , referentes à origem das rendas pessoais, com a estrutura do emprego antes descrita à base sobretudo dos elementos do quadro 2 . É que, no quadro 9, o setor informal aparece só na qualidade de ocupação principal, gerando $60,8 \%$ dos ganhos médios das pessoas economicamente ativas, enquanto no quadro 2 sua contribuição para o emprego monta a 40,9\% das oportunidades criadas. A disparidade significa uma taxa de remuneração por pessoa mais elevada para a mão-de-obra informal do que para a formal, fato possível de acontecer, mesmo nas proporções reveladas, por várias razões. Em primeiro lugar, os ganhos do trabalhador informal costumam oscilar, são instáveis e, portanto, difíceis de contabilizar. Isso sugere a possibilidade de falhas na informação. No entanto, o ganho médio pode ser realmente elevado defronte das receitas obtidas no setor formal, como maneira de compensar o trabaIhador pelas relações trabalhistas bambas, desprotegidas, que esse mantém com as ocupações informais. Além disso, no salário da mão-de-obra informal pode estar computada alguma parcela referente a insumos utilizados na prestação de serviços, inclusive importâncias que dizem respeito ao uso de ferramentas pertencentes ao trabalhador - como sucede no caso de um carpinteiro, por exemplo tornando-se impraticável estimá-las para se chegar 
ao salário líquido do profissional. Por último, vale a pena não se descartar a possibilidade de gantios informais sazonalmente altos, peculiaridade não trivial no caso dos salários fixos dos trabalhadores do setor formal. Estes, dentro da população pesquisada, tendem a representar um estrato social governado pelo salário mínimo, com remuneração média realmente ínfima. Torna-se admissível, por conseguinte, aceitar a evidência do quadro 9 como indicativa do panorama de pobreza que circunscreve a população estudada, a qual dependeria, basicamente, da ligação - frouxa, instável, nem sempre vista com bons olhos pelas autoridades governamentais com o setor informal, para a formação de seu poder aquisitivo, para o provimento de sua subsistência. Como retrata o quadro 9 , residirá no setor informal a principal fonte de renda do trabalhador de mais baixa condição social de Fortaleza, fenômeno que tem uma contrapartida de total similitude no caso de Salvador. ${ }^{15}$

\section{Quadro 9}

Fortaleza - Composição da renda pessoal da população estudada, por ocupação e por classe de renda - junho/1978

\section{(porcentagens)}

\begin{tabular}{|c|c|c|c|c|c|c|}
\hline \multirow[b]{2}{*}{ Classes de renda } & \multicolumn{2}{|c|}{ Ocup. Principal } & \multicolumn{2}{|c|}{ Ocup. Secundária } & \multirow[b]{2}{*}{$\begin{array}{l}\text { Outras } \\
\text { rendas }\end{array}$} & \multirow[b]{2}{*}{ Total } \\
\hline & Formal & Informal & Formal & Informal & & \\
\hline $\begin{array}{l}\text { (1) Até } 550 \\
\text { (2) } 551-1.100 \\
\text { (3) } 1.101-2.200 \\
\text { (4) } 2.201-4.400 \\
\text { (5) } 4.401=6.600 \\
\text { (6) } 6.101 \text { e mais } \\
\text { Total }\end{array}$ & $\begin{array}{r}3,8 \\
14,6 \\
39,0 \\
25,2 \\
27,9 \\
16,9 \\
28,7\end{array}$ & $\begin{array}{l}64,6 \\
61,5 \\
53,8 \\
72,0 \\
72,1 \\
83,1 \\
60,8\end{array}$ & $\begin{array}{l}0,4 \\
0,3 \\
= \\
= \\
\overline{0,1}\end{array}$ & $\begin{array}{l}0,2 \\
1,4 \\
0,8 \\
0,9 \\
- \\
\overline{0,8}\end{array}$ & $\begin{array}{c}31,0 \\
22,2 \\
6,4 \\
1,9 \\
- \\
\overline{9}, 6\end{array}$ & $\begin{array}{l}100,0 \\
100,0 \\
100,0 \\
100,0 \\
100,0 \\
100,0 \\
100,0\end{array}$ \\
\hline
\end{tabular}

Fonte: Pesquisa direta da FUNDAJ.

Considerando-se a informação do nível de renda da população pesquisada em Fortaleza, com a ajuda do quadro 10, constata-se uma situação de inequívoca marginalidade econômica do grupo em questão. De fato, a renda média mensal por família, em junho de 1978, aí encontrada, tinha um valor (2.047 cruzeiros) que ultrapassava o salário mínimo da RMF em apenas $84 \%$, enquanto Salvador, dois meses antes, o excesso era $343 \% .{ }^{16}$ Pode-se dizer que os universos de referência que foram utilizados nos levantamentos das duas capitais - e cuja definição se deveu a critérios mais geográficos do que sócio-econômicos - não permitem completa comparabilidade. Mas não deixa de patentear-se um nível de pobreza absoluta mais nítido, mas iniludível no caso de Fortaleza, onde, mesmo com a pesquisa efetuando-se depois da vigência do salário mínimo de maio de 1978 - ao passo que o inquérito de Salvador data de antes do citado salário - - a renda mensal de uma família caracterizada como pobre ( 2.047 cruzeiros) ficava em nível bastante inferior ao da congênere família salvadorense (3.852 cruzeiros).
De modo que é irrecusável a conclusão de que a população de Fortaleza, dentro da qual se enquadram os ofertantes de mão-de-obra ao setor informal, constitui lídimo exemplo de segmento urbanomarginal, com irrisório poder aquisitivo. Segmento urbano-marginal esse distinto, sem dúvida alguma, do que se selecionou para estudo na Região Metropolitana de Salvador, haja vista que a renda familiar média daquele equivalente a $27 \%$ da cifra encontrada para a cidade de Fortaleza como um todo $(7.601$ cruzeiros, em junho de 1978)17, enquanto em Salvador a razão de proporcionalidade situava-se nos $60 \% .18$

A caracterização per capita do panorama observado, envidentemente, não pode fugir à linha diretora do horizonte de pobreza que acima se tentou traçar. Alude-se aqui à manifestação do problema em termos de renda por habitante tão-só com a finalidade de deixar bem exposta a natureza das dificuldades de sobrevivência que a população focalizada deve enfrentar. De acordo com o quadro 10 , a renda por indivíduo no contingente pesquisado valia, em junho de 1978, 4.533 cruzeiros - ou seja, 251 dólares ${ }^{19}$ - , representando a insignificante fração de $16,0 \%$ da média nacional (28.338 cruzeiros).20 Estima-se, com apoio nos dados da pesquisa efetuada em Fortaleza21, que quase $2 / 3$ da população de Fortaleza aufere rendimentos comparáveis com os da população-base da oferta de mão-de-obra ao setor informal. Isto implica uma situação de grande desnivel de condição social, traduzida em graus diversos de miséria e penúria contemplados pela classe de onde provém a força de trabalho engajada em atividades informais. Essa população pobre, segundo o quadro 11 , é formada de famílias que, em $18,4 \%$ dos casos, vivem com menos de um salário mínimo de rendimento e, em quase $2 / 3$ (65,9\% dos casos), com menos de dois salários mínimos. São resultados alarmantes, uma vez que não se ignora o tremendo esforço que significa para uma farnília equilibrar seu orçamento dentro das fronteiras de um ou dois salários mínimos. Normalmente, é preciso contar aí com a ajuda de familiares ou de amigos, com a caridade pública ou com o recurso a pequenos delitos e contravenções maiores. O trabalho informal também surge, nesse contexto, com uma fisionomia que não é pujante, porque está fortemente ligado à estratégia de sobrevivência dos pobres em face da fome. Em outras palavras, o aparecimento aí de uma oferta de mão-de-obra informal não se dá como resposta a estímulo de preço que descrevesse a relação funcional normalmente associada à oferta no mercado de trabalho; antes, o aparecimento é decorrente de urgências pessoais que necessitam de pronto socorro.

Termina-se, portanto, com um espetáculo de baixa condição social, de miséria inequívoca que, em 


\section{Quadro 10}

Fortaleza - Renda por família e por pessoa na população pesquisada, por classe de renda familiar mensal - junho/1978

\begin{tabular}{|c|c|c|c|c|c|c|}
\hline \multirow{2}{*}{$\begin{array}{l}\text { Classes de renda } \\
\text { familiar mensal } \\
\text { (Cr\$) }\end{array}$} & \multicolumn{2}{|c|}{ N: total } & \multirow[b]{2}{*}{$\begin{array}{c}\text { Renda } \\
\text { total } \\
\text { (Crs) } \\
\mathrm{C} \\
\end{array}$} & \multirow[b]{2}{*}{$\begin{array}{c}\text { Pessoas } \\
\text { por fa- } \\
\text { milia } \\
\text { B/A } \\
\end{array}$} & \multicolumn{2}{|c|}{ Renda média (Cr\$) } \\
\hline & $\begin{array}{c}\text { Fami- } \\
\text { lias } \\
\text { A } \\
\end{array}$ & $\begin{array}{l}\text { Pes- } \\
\text { soas } \\
\mathrm{B}\end{array}$ & & & $\begin{array}{c}\text { Por fa- } \\
\text { milia } \\
\text { C/A }\end{array}$ & \begin{tabular}{|c|}
$\begin{array}{c}\text { Por pessoa } \\
\text { (anual) } \\
12 . \mathrm{C} / \mathrm{B} \\
\end{array}$ \\
\end{tabular} \\
\hline $\begin{array}{l}\text { (1) Até } 550 \\
\text { (2) } 551-1.100 \\
\text { (3) } 1.101-2.200 \\
\text { (4) } 2.201-4.400 \\
\text { (5) } 4.401-6.600 \\
\text { (6) } 6.601 \text { e mais } \\
\text { Total }\end{array}$ & $\begin{array}{r}24 \\
119 \\
369 \\
214 \\
37 \\
14 \\
777\end{array}$ & $\begin{array}{r}77 \\
524 \\
1.974 \\
1.271 \\
270 \\
94 \\
4.210\end{array}$ & $\begin{array}{r}10.577 \\
99.754 \\
559.173 \\
619.011 \\
184.956 \\
116.951 \\
1.590 .422\end{array}$ & $\begin{array}{l}3,2 \\
4,4 \\
5,3 \\
5,9 \\
7,3 \\
6,7 \\
5,4\end{array}$ & $\begin{array}{r}441 \\
838 \\
1.515 \\
2.893 \\
4.999 \\
8.354 \\
2.047 \\
\end{array}$ & $\begin{array}{r}1.648 \\
2.284 \\
3.399 \\
5.844 \\
8.220 \\
14.930 \\
4.533\end{array}$ \\
\hline
\end{tabular}

Fonte: Pesquisa direta da FUNDAJ.

\section{Quadro 11}

Fortaleza - Número relativo de famílias e de pessoas ativas, por classe de renda - junho/1978

\begin{tabular}{|c|c|c|c|c|}
\hline \multirow{2}{*}{$\begin{array}{l}\text { Classes de renda } \\
\text { familiar e pessoal(a) }\end{array}$} & \multicolumn{2}{|c|}{$\begin{array}{l}\% \text { do } n: \text { de } \\
\text { famílias }\end{array}$} & \multicolumn{2}{|c|}{$\begin{array}{c}\% \text { do } n: \text { de } \\
\text { pessoas ativas(b) }\end{array}$} \\
\hline & Simples & $\begin{array}{l}\text { Acumu- } \\
\text { lada }\end{array}$ & Simples & $\begin{array}{l}\text { Acumu- } \\
\text { lada }\end{array}$ \\
\hline 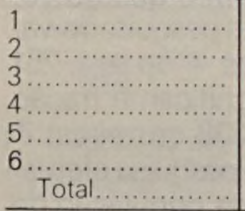 & $\begin{array}{r}3,1 \\
15,3 \\
47,5 \\
27,5 \\
4,8 \\
1,8 \\
100,0\end{array}$ & $\begin{array}{r}3,1 \\
18,4 \\
65,9 \\
93,4 \\
98,2 \\
100,0 \\
-\end{array}$ & $\begin{array}{r}14,8 \\
27,7 \\
47,3 \\
8,6 \\
1,1 \\
0,4 \\
100,0\end{array}$ & $\begin{array}{r}14,8 \\
42,5 \\
89,8 \\
98,4 \\
99,5 \\
100,0 \\
-\end{array}$ \\
\hline
\end{tabular}

Fonte: Pesquisa direta da FUNDAJ.

Notas: (a) - Mesmas classes de renda dos Quadros 9 e 10.

(b) - Não se trata do número de pessoas ativas dentro dos intervalos de renda familiar, e sim dentro dos intervalos de renda pessoal. Ou seja, v.g., o indivíduo A que ganha 400 cruzeiros de renda, entra no intervalo 1, muito embora, junto com o indivíduo $B$, que ganha 1.900 cruzeiros (e pertence ao intervalo 3 ), faça parte de uma familia que está incluída no intervalo 4 (renda de 2.300 cruzeiros).
Fortaleza, explica por que mais de $2 / 5(42,5 \%)$ das pessoas ativas no grupo estudado, como assegura o quadro 11, não obtêm sequer um salário mínimo de renda mensal, chegando, por sua vez, a praticamente $9 / 10$ a fatia dos trabalhadores que devem se contentar com menos de dois salários mínimos. Ou seja, na população objeto de pesquisa, é excepcional a freqüência de remunerações por pessoa ativa22 acima de um valor tão módico com 123 dólares por mês - que é a cifra correspondente a duas vezes um salário mínimo. De sua parte, a média das receitas de um trabalhador, conforme registra o quadro 12, atinge apenas a 1.297 cruzeiros (ou seja, 72 dólares), com os ganhos da mulher que trabalha apresentando a exígua importância mediana de 831 cruzeiros, a qual equivale a pouco mais da metade $(55 \%)$ da importância percebida pelos homens (1.501 cruzeiros). Em termos da mão-de-obra feminina, de modo geral, o flagrante proporcionado pelo quadro 12 denuncia não somente uma esperada posição subalterna com respeito à mão-de-obra masculina, como também o patamar de verdadeira indigência em que se situam as mulheres que trabaIham, das quais $72,9 \%$ - quase $3 / 4$, pois - conseguem ganhar um só salário mínimo de renda mensal. Pode haver engano nos dados apresentados; mas mesmo que eles representassem uma subestimação equivalente à metade do valor real da renda, ainda assim se estaria diante de um quadro digno de atenção e questionamento. E o fato é que, da experiência do estudo de campo, nada leva a crer que as situações descritas, fotografadas e sugeridas pelos quadros 10 e 12, particularmente, escamoteiem a face genuína da realidade.

Quadro 12 Fortaleza - Renda mensal por pessoa ativa na população estudada, por sexo e por classe de renda pessoal
- junho/1978

\begin{tabular}{|c|c|c|c|c|c|c|c|}
\hline \multirow[b]{2}{*}{ Especificações } & \multicolumn{7}{|c|}{ Classes de renda pessoal mensal (salários mínimos) ${ }^{*}$} \\
\hline & $\begin{array}{c}\text { Até } \\
1 / 2 \text { salário } \\
\text { minimo }\end{array}$ & $1 / 2-1$ & $1-2$ & $2-4$ & $4-6$ & $\begin{array}{l}\text { Mais } \\
\text { de } 6\end{array}$ & Total \\
\hline $\begin{array}{l}\text { 1. Sexo masculino } \\
\text { Renda total (A), Cr\$ } \\
\text { Número de pessoas (B) } \\
\% \text { do número de pessoas } \\
\text { Renda média (A/B), Cr\$ } \\
\text { 2. Sexo feminino }\end{array}$ & $\begin{array}{c}20.213 \\
53 \\
6,2 \\
381\end{array}$ & $\begin{array}{c}170.462 \\
196 \\
23,0 \\
870\end{array}$ & $\begin{array}{c}690.918 \\
488 \\
57,2 \\
1.416\end{array}$ & $\begin{array}{r}279.461 \\
97 \\
11.4 \\
3.067\end{array}$ & $\begin{array}{c}71.100 \\
14 \\
1,6 \\
5.079\end{array}$ & $\begin{array}{r}48.400 \\
5 \\
0,6 \\
9.680\end{array}$ & $\begin{array}{c}1.280 .554 \\
853 \\
100,0 \\
1.501\end{array}$ \\
\hline $\begin{array}{l}\text { Rúmero de pessoas (D) } \\
\% \text { do número de pessoas } \\
\text { Renda média (C/D), Cr\$ } \\
\text { 3. Total }\end{array}$ & $\begin{array}{c}46.172 \\
128 \\
34,3 \\
361\end{array}$ & $\begin{array}{r}113.944 \\
144 \\
38,6 \\
791\end{array}$ & $\begin{array}{r}124.832 \\
92 \\
24,7 \\
1.357\end{array}$ & $\begin{array}{r}24.920 \\
9 \\
2,4 \\
2.769\end{array}$ & $\begin{array}{l}- \\
- \\
-\end{array}$ & $\overline{-}$ & $\begin{array}{c}309.868 \\
373 \\
100,0 \\
831\end{array}$ \\
\hline $\begin{array}{l}\text { Renda total }(A+C), C r \$ \\
\text { Número de pessoas }(B+D) \\
\text { Renda média }(A+C) /(B+D), C r \$\end{array}$ & $\begin{array}{r}66.385 \\
181 \\
367 \\
\end{array}$ & $\begin{array}{r}284.406 \\
340 \\
836 \\
\end{array}$ & $\begin{array}{r}815.750 \\
580 \\
1.406 \\
\end{array}$ & $\begin{array}{r}304.381 \\
106 \\
2.871 \\
\end{array}$ & $\begin{array}{r}71.100 \\
14 \\
5.079 \\
\end{array}$ & $\begin{array}{r}48.400 \\
5 \\
9.680 \\
\end{array}$ & $\begin{array}{r}1.590 .422 \\
1.226 \\
1.297 \\
\end{array}$ \\
\hline
\end{tabular}

- Nota: Salário mínimo de junho de 1978, em Fortaleza: Cr\$1.111,20. 


\section{Algumas características do emprego da mão-de-obra de baixa renda de Fortaleza}

A população objeto do presente estudo compreende realmente um segmento bastante desprotegido do universo social de Fortaleza, haja vista que $4 / 5$ dos trabalhadores que dela fazem parte não contam nem com carteira assinada nem com previdência social. Os resultados da pesquisa a esse respeito, e por grau de instrução da mão-de-obra, oferecendo eloqüente visão do emprego da população de baixa renda da capital do Ceará, assim se ordenam:

\begin{tabular}{l|c|c|c|c|c}
\hline Situaçăo legal do trabalhador & $\begin{array}{c}\text { Anal- } \\
\text { fabeto }\end{array}$ & $\begin{array}{c}\text { Alfabe- } \\
\text { tizado }\end{array}$ & $\begin{array}{c}\text { Pri- } \\
\text { mário }\end{array}$ & $\begin{array}{c}\text { Secun - } \\
\text { dário }\end{array}$ & Total \\
\hline $\begin{array}{l}\text { Trabalhadores sem carteira assinada, } \\
\text { sem previdência social................. }\end{array}$ & $86,5 \%$ & $78,9 \%$ & $75,2 \%$ & $70,0 \%$ & $80,6 \%$ \\
$\begin{array}{l}\text { Trabalhadores com alguma forma de } \\
\text { proteçăo trabalhista..................... }\end{array}$ & $13,5 \%$ & $21,1 \%$ & $24,8 \%$ & $30,0 \%$ & $19,4 \%$ \\
\hline \multicolumn{1}{c}{ Total } & 100,0 & 100,0 & 100,0 & 100,0 & 100,0 \\
\hline
\end{tabular}

Percebe-se nesses dados uma clara correlação positiva entre nível de treinamento dos indivíduos e a existência de proteção ao trabalhador, mas essa constatação não consegue encobrir a natureza predominantemente lassa da atividade profissional das pessoas ativas cujas ligações com o setor informal são estreitas. Na verdade, apenas $19,4 \%$ dessas pessoas contam com alguma das franquias elementares que a legislação trabalhista proporciona - todas as demais permanecendo à margem do regime protetor. Esse é, sem dúvida, um aspecto característico da síndrome do emprego informal, valendo ressaltar que são os próprios trabalhadores que, exercendo por conta própria atividades informais, não se interessam, no tocante à carteira profissional, por sua regularização. A evidenciação dessa peculiaridade é fornecida pelo quadro 13 , que revela igualmente, no caso dos empregados, que a principal razão para não se ter carteira assinada reside na má vontade do empregador. Falta de oportunidade é também um fator importante para a não assinatura, conforme explica o quadro 13.

\section{Quadro 13}

Fortaleza - Razões para a não assinatura da carteira de trabalho, por posição da mão-de-obra "na ocupação - junho/1978 — (porcentagens)

\begin{tabular}{|c|c|c|c|c|c|c|}
\hline \multirow[b]{2}{*}{$\begin{array}{c}\text { Posição } \\
\text { na } \\
\text { Ocupação }\end{array}$} & \multicolumn{6}{|c|}{ Razס̄es } \\
\hline & $\begin{array}{l}\text { O patrão } \\
\text { năo quis } \\
\text { assinar. }\end{array}$ & $\begin{array}{l}\text { Todos tra- } \\
\text { balham } \\
\text { sem car- } \\
\text { teira as- } \\
\text { sinada. }\end{array}$ & $\begin{array}{l}\text { Não } \\
\text { quis } \\
\text { assi- } \\
\text { nar. }\end{array}$ & $\begin{array}{l}\text { Trabalha } \\
\text { por conta } \\
\text { propria. } \\
\text { Não se } \\
\text { interessa }\end{array}$ & $\begin{array}{c}\text { Năo } \\
\text { teve } \\
\text { oportu- } \\
\text { nidade. }\end{array}$ & Total \\
\hline $\begin{array}{l}\text { Empregador } \\
\text { Empregado } \\
\text { Autônomo formal } \\
\text { Autônomo informal } \\
\text { Ambulante } \\
\text { Aprendiz } \\
\text { Total }\end{array}$ & $\begin{array}{l}\overline{34,9} \\
\overline{10}, 6 \\
- \\
\overline{14}, 0\end{array}$ & $\begin{array}{r}\overline{9}, 5 \\
\overline{5} \\
11,5 \\
100,0 \\
6,4\end{array}$ & $\begin{array}{c}\overline{7}, 9 \\
\overline{2}, 4 \\
11, \overline{1} \\
\overline{3,4}\end{array}$ & $\begin{array}{r}100,0 \\
22,2 \\
100,0 \\
64,5 \\
66,7 \\
\overline{58,0}\end{array}$ & $\begin{array}{l}\overline{25,0} \\
\overline{17}, 0 \\
11, \overline{1} \\
\overline{18,2}\end{array}$ & $\begin{array}{l}100,0 \\
100,0 \\
100,0 \\
100,0 \\
100,0 \\
100,0 \\
100,0\end{array}$ \\
\hline
\end{tabular}

Fonte: Pesquisa direta da FUNDAJ.
Entre os trabalhadores por conta própria, cujo desinteresse pela assinatura da carteira é ilustrado pelo quadro 13, não se registra tampouco maior tendência para a satisfação de exigências de cadastramento junto à prefeitura de Fortaleza ou ao fisco estadual do Ceará. De fato, o quadro 14 informa, no caso desse contingente de autônomos, que as dimensões dos negócios explorados são tão pequenas que não compensam qualquer esforço de formalização legal em $81,4 \%$ dos casos. Esta é mais uma faceta, na verdade, do modelo de economia do setor informal, ou seja, a diminuta escala de operações dos negócios que dela participam, o que mostra a impropriedade, sob o ponto de vista econômi$\mathrm{co}$, da tarefa de tornar legal a atividade. Não há, portanto, possibilidades concretas nem realismo em se pensar numa política de formalização do setor informal, pelo menos nos moldes em que se opera essa formalização a nível dos grandes empreendimentos Nem há, tampouco, tradição que ligue, no universo estudado de Fortaleza, as pessoas englobadas pelas atividades informais aos setores organizados da economia. Basta mencionar que no levantamento efetuado entre a população de baixa renda da capital cearense, $71,4 \%$ dos trabalhadores informais nunca trabalharam em firmas organizadas. Noutras palavras, mais de 7 em cada 10 indivíduos definidos como mão-de-obra informal, não tiveram qualquer experiência em empresa de maior porte, moderna, formal, fazendo prever os inconvenientes de rápida transformação dessas pessoas em contingente trabalhador do compartimento avançado da economia.

\section{Quadro 14}

Fortaleza - Razões para o não cadastramento na prefeitura de Fortaleza e na Secretaria da Fazenda do Ceará dos Trabalhadores informais autônomos - junho/1978

\begin{tabular}{c|r|c|r}
\hline $\begin{array}{c}\text { Razões para o não } \\
\text { cadastramento }\end{array}$ & Prefeitura & $\begin{array}{c}\text { Secretaria } \\
\text { da Fazenda }\end{array}$ & Total \\
\hline Não dispõe de recursos.. & 8,9 & 6,1 & 7,5 \\
Não teve oportunidade. & 2,0 & 6,1 & 4,0 \\
O negócio é muito peque & & & \\
no, não compensa......... & 83,2 & 79,6 & 81,4 \\
Falta de tempo ............ & 1,0 & - & 0,5 \\
Não se interessa............ & 4,9 & 8,2 & 6,5 \\
Total..................... & 100,0 & 100,0 & 100,0 \\
\hline
\end{tabular}

Fonte: Pesquisa direta da FUNDAJ.

Semelhantemente a Salvador, onde nenhum tipo de ocupação parece destacar-se de maneira categoricamente hegemônica dos demais 23 , os resultados relativos a Fortaleza - quanto aos ofícios desempenhados pela população de baixa renda pesquisada - mostram a presença flagrante de um número de ocupações que inclui pessoal de obras (mestres, pedreiros, serventes etc.), vendedores am- 
bulantes e mão-de-obra que atua na faixa portuária além do vago grupo de outros tipos - conforme dá testemunho o quadro 15.24 Dessas ocupações, a mais espessamente informal parece ser a do ambulante, seguida das que se escondem em 'outros' o que, denotando a própria dificuldade de classificá-las, atesta de maneira convincente sua informalidade. 0 quadro 16, a propósito, confere às costureiras, alfaiates etc., aos biscateiros, aos profissionais e práticos tipo enfermeiro, laboratorista, professor (primário), aos pintores, e à mão-de-obra de higiene e beleza - além dos já citados ambulantes e outros - a mais nítida caracterização de ocupações informais em Fortaleza. O que dizer, porém, de serviçais domésticos remunerados e de faxineiros, lavadeiras etc. que, considerados no quadro $16 \mathrm{sob}$ a égide predominante de empregados, podem dar a impressão de um estágio mais avançado de relações de trabalho no caso? Evidentemente, é inverídica tal conjectura e o que fica demonstrado, então, é que entre empregados domésticos incluem-se tanto autônomos quanto trabalhadores informais, não sendo suficiente referir à taxionomia adotada para a posição na ocupação (empregador, empregado, autônomo formal, autônomo informal, aprendiz, funcionário público e aposentado) para se ter uma clara delimitação de fronteiras. Dessa forma, muito mais do que prestar-se para o relacionamento das ocupações informais, definindo sua importância, o que o quadro 15 faz é mapear o perfil ocupacional da população de baixa renda de Fortaleza. Nesse particular, determina-se a hierarquia das ocupações por sexo, com uma clara constatação, a saber: entre as mulheres, há um grupo numeroso de indivíduos $(24,6 \%)$ cujo trabalho toma formas variadas, fugindo às especificações enumeradas no quadro 15 , sobrando assim para a categoria de outros. Afora isso, a população de mulheres liga-se principalmente ao emprego doméstico (serviços domésticos remunerados, serviços de copa e cozinha e faxina, lavadeira etc., representando $25,4 \%$ das ocupações) e à costura $(15,2 \%)$. Fica a mão-de-obra feminina, dessa maneira, enquadrada majoritariamente no setor informal, haja vista que as ocupações há pouco ressaltadas, inclusive a categoria 'outros', segundo o quadro 16 (em concordância ainda com a experiência dos pesquisadores), representam quase $2 / 3$ do trabalho das mulheres.

Quanto aos homens, a ocupação líder é a de obras $(23,4 \%$ da população), vindo depois do grupo de trabalho em porto $(12,6 \%)$, o dos ambulantes $(10,2 \%)$, o de outros $(7,8 \%)$ e, mais atrás, o dos mecânicos $(5,1 \%)$ - a crer na lista exibida pelo quadro 15. Dessas ocupações, aparentemęnte, seriam basicamente informais as de ambulantes e outros, muito embora uma proporção elevada do pessoal de obras se constitua de autônomos informais. A leitura do quadro 15 , em combinação com o quadro
16, sugere, no todo, menor informalidade das ocupações masculinas em comparação com as femininas, ainda que valha a advertência de que as fronteiras entre as formas de posição na ocupação usadas no quadro 16 não sejam muito nítidas. Certamente, o peso do setor informal, entre a população trabalhadora masculina, é maior do que os quadros 15 e 16 deixam entrever. E seguramente, tanto os trabalhadores homens como mulheres não revelam maior proximidade das ocupações mais tipicamente formais do quadro 15, como profissional liberal, operário industrial e comerciário. Isso reforça a constatação de que a PEA da população pesquisada mantém vínculos mais íntimos com o setor informal do que com os setores avançados, feito que é ainda mais verdadeiro com respeito à força de trabatho feminina. Na verdade, o quadro 17 reforça essa

\section{Quadro 15}

Fortaleza - Tipo de ocupação da PEA da população pesquisada, por sexo - junho/1978

(porcentagens)

\begin{tabular}{|c|c|c|c|}
\hline \multirow{2}{*}{ Tipo de ocupação } & \multicolumn{3}{|c|}{ Sexo } \\
\hline & Masculino & Feminino & Total \\
\hline $\begin{array}{l}\text { Costureira, alfaiate etc. } \\
\text { Comércio ambulante } \\
\text { Aposentado } \\
\text { Biscateiro } \\
\text { Trabalho em madeira } \\
\text { Agricultor } \\
\text { Cobrador } \\
\text { Serviços domésticos } \\
\text { remunerados } \\
\text { Profissionais e } \\
\text { práticos(a) } \\
\text { Profissional liberal } \\
\text { Trabalho em fotografia } \\
\text { Serviços de copa e } \\
\text { cozinha } \\
\text { Trabalho em porto } \\
\text { Operário industrial } \\
\text { Carregador, entregador } \\
\text { Faxineiro, lavadeira, } \\
\text { lavador, zelador } \\
\text { Mecânico } \\
\text { Transportador(b) } \\
\text { Comerciário } \\
\text { Pessoal de obras } \\
\text { Pintor } \\
\text { Funcionário público } \\
\text { Higiene e beleza } \\
\text { Recepcionista, vigia etc. } \\
\text { Pescador } \\
\text { Outros(c) } \\
\text { Impreciso } \\
\text { Total }\end{array}$ & $\begin{array}{r}0,6 \\
10,2 \\
9,4 \\
1,1 \\
4,4 \\
0,2 \\
0,5 \\
0,1 \\
0,1 \\
- \\
0,1 \\
1,8 \\
12,6 \\
0,1 \\
2,5 \\
0,1 \\
5,1 \\
2,2 \\
3,4 \\
23,4 \\
2,9 \\
4,1 \\
0,2 \\
4,6 \\
2,3 \\
7,8 \\
0,2 \\
100,0 \\
\end{array}$ & $\begin{array}{r}15,2 \\
9,4 \\
12,6 \\
0,3 \\
0,3 \\
0,3 \\
0,3 \\
11,7 \\
2,3 \\
0,6 \\
- \\
1,7 \\
- \\
- \\
- \\
12,0 \\
0,6 \\
2,6 \\
0,8 \\
-1,2 \\
1,2 \\
1,7 \\
24,6 \\
0,6 \\
100,0\end{array}$ & $\begin{array}{r}4,9 \\
9,9 \\
10,4 \\
0,9 \\
3,1 \\
0,3 \\
0,4 \\
3,6 \\
0,8 \\
0,2 \\
0,1 \\
1,8 \\
8,8 \\
0,1 \\
1,8 \\
3,6 \\
3,6 \\
1,7 \\
3,1 \\
16,7 \\
2,0 \\
3,2 \\
0,5 \\
3,7 \\
1,6 \\
12,8 \\
0,3 \\
100,0\end{array}$ \\
\hline
\end{tabular}

Fonte: Pesquisa direta da FUNDAJ.

Notas: (a) Inclui enfermeiro, professor, laboratorista, profissionais de nível médio.

(b) Inclui motorista de táxi, de ônibus, carroceiro etc.

(c) Inclui trabalho em mais de uma atividade, simultaneaménte, sem que se possa precisar a mais importante. 
(porcentagens)

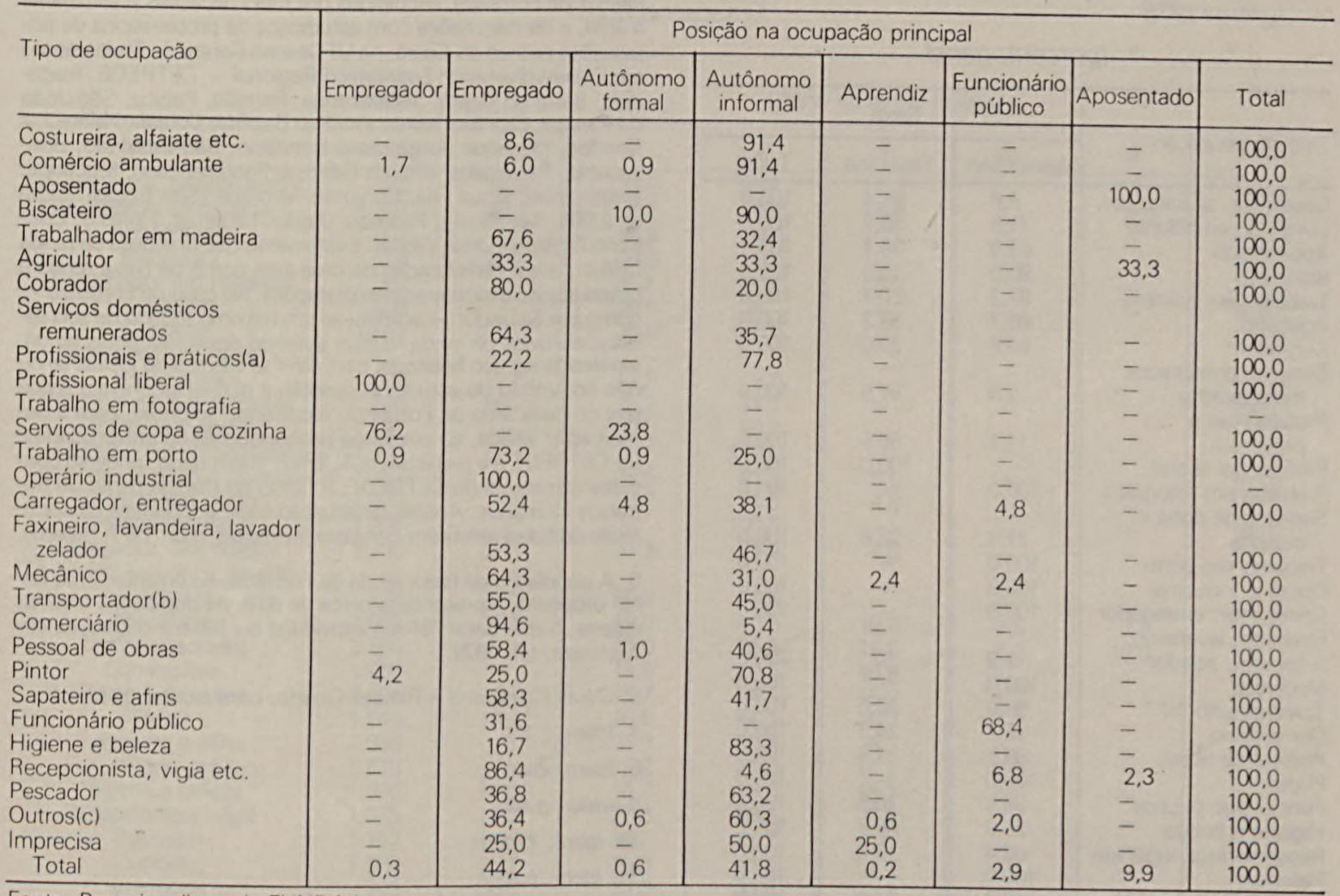

Fonte: Pesquisa direta da FUNDAJ.

Notas: (a) Inclui enfermeiro, professor, laboratorista, profissionais de nivel médio.

(a) Inclui motorista de táxi, de ônibus, carroceiro etc.

(b) Inclui trabalho em mais de uma atividade, simultaneamente, sem que possa precisar a mais importante.

conclusão ao mostrar que, no contingente populacional de baixa renda de Fortaleza, o efetivo da PEA de mulheres supera o da PEA de homens em costura, serviços domésticos remunerados, profissionais e práticos, profissões liberais, faxineiros, lavadeira etc. , higiene e beleza e outros que, com exceção única de profissões liberais, são ocupações que o quadro 16 indica inequivocamente pertencerem ao setor informal.

Em termos de renda, a maior intensidade de ligação do trabalhador com o setor informal aparece geralmente correspondida por remuneraç̃es menores e uma tendência de as pessoas ativas se concentrarem nos dois primeiros escalões da distribuição da renda. Isso, pelo menos, é o que se infere de rápida inspeção do quadro 18 , segundo o qual as ocupações que proporcionam menores ganhos são serviços domésticos remunerados $(500$ cruzeiros mensais por trabalhador, ou seja, $45 \%$ do salário mí- nimo da época do levantamento), profissionais e práticos ( 586 cruzeiros) biscateiro ( 753 cruzeiros), costureira/alfaiate (762 cruzeiros) e faxineiro, lavadeira etc. ( 774 cruzeiros) - ocupações todas elas tipicamente informais. Todavia, entre os tipos que pagam melhores salários - transportador ( 2.550 cruzeiros), mecânico (2.022 cruzeiros), pintor (1.643 cruzeiros) e funcionários público ( 1.619 cruzeiros) - encontrase a ocupação informal de pintor. A tendência geral é, não obstante, para uma certa diferenciação, que põe no pé da escada de rendas as atividades menos protegidas. De qualquer forma, o quadro 18 deixa patente que inexiste grande disparidade de remuneração ocupacional no âmbito da força de trabatho compreendida por este estudo, antes sugerindo a existência de um universo bastante homogêneo, constituído pelas pessoas que compõem a PEA pesquisada. Nesse universo, quanto às rendas que geram, as ocupações se disporiam de acordo com a 
Quadro 17

Fortaleza - Sexo das pessoas economicamente ativas na população pesquisada, por tipo de ocupação - Junho/1978

(porcentagens)

\begin{tabular}{l|r|c|c}
\hline \multirow{2}{*}{ Tipo de ocupação } & \multicolumn{3}{|c}{ Sexo } \\
\cline { 2 - 4 } & Masculino & Feminino & Total \\
\hline Costureira, alfaiate, etc. & 8,6 & 91,4 & 100,0 \\
Comércio ambulante & 71,8 & 28,2 & 100,0 \\
Aposentado & 63,9 & 36,1 & 100,0 \\
Biscateiro & 90,0 & 10,0 & 100,0 \\
Trabalho em madeira & 97,3 & 2,7 & 100,0 \\
Agricultor & 66,7 & 33,3 & 100,0 \\
Cobrador & 80,0 & 20,0 & 100,0 \\
Serviços domésticos & 2,4 & 97,6 & 100,0 \\
remunerados & & & \\
Profissionais e & 11,1 & 88,9 & 100,0 \\
práticosla) & - & 100,0 & 100,0 \\
Profissional liberal & - & 100,0 \\
Trabalho em fotografia & 100,0 & - & \\
Servicos de copa e & 71,4 & 28,6 & 100,0 \\
cozinha & 100,0 & - & 100,0 \\
Trabalho em porto & 100,0 & - & 100,0 \\
Operário industrial & 100,0 & - & 100,0 \\
Carregador, entregador & & & \\
Faxineiro, lavadeira, & 2,3 & 97,7 & 100,0 \\
lavador, zelador & 100,0 & - & 100,0 \\
Mecânico & 90,0 & 10,0 & $.100,0$ \\
Transportador(b) & 75,7 & 24,3 & 100,0 \\
Comerciário & 98,5 & 1,5 & 100,0 \\
Pessoal de obras & 100,0 & - & 100,0 \\
Pintor & 89,5 & 10,5 & 100,0 \\
Funcionário público & 33,3 & 66,7 & 100,0 \\
Higiene e beleza & 86,4 & 13,6 & 100,0 \\
Recepcionista, vigia etc. & 100,0 & - & 100,0 \\
Pescador & 43,0 & 57,0 & 100,0 \\
Outros(c) & 50,0 & 50,0 & 100,0 \\
Impreciso & 70,4 & 29,6 & 100,0 \\
\hline Total & & \\
\hline & &
\end{tabular}

Fonte: Pesquisa direta da FUNDAJ

Notas: (a) Inclui enfermeiro, professor, laboratorista, profissionais de nível médio.

(b) Inclui motorista de táxi, de ônibus, carroceiro etc

(c) Inclui trabalho em mais de uma atividade, simultaneamente, sem que se possa precisar a mais importante. escala - menos cardinal que ordinal - do quadro
18.

\section{Notas}

1. Que é parte de um estudo mais amplo efetuadø na Fundação Joaquim Nabuco sob os auspícios da SUDENE e do Ministério do Trabalho.

2. A informação de 1970 é da FIBGE, Censo Demográfico - Ceará (1970). A de 1978 resulta de projeção, supondo taxas de crescimento demográfico de 4,7 e 5,4\% para a RMF e Fortaleza, respectivamente, de acordo com a AUMEF, in Projeções com base na taxa de crescimento da população urbana e rural no período
$60 / 70$.
3. Ver Clóvis Cavalcanti e Renato Duarte, O setor informal de Salvador: dimensões, natureza, significação (Recife, FUNDAJ - SU DENE, MTb, 1980), capítulo II

4. Na pesquisa, localizou-se o trabalho de campo nos seguintes bairros de Fortaleza, escolhidos por meio de visitas preliminares à área, e de discussões com estudiosos da problemática de populações pobres do Ceará, na UFCe e no Centro de Treinamento em Desenvolvimento Econômico Regional - CETREDE: Alaga diço, Barra do Ceará, Jacarecanga, Parreão, Papicu, São João do Tanapé, Dionísio Torres, Antônio Bezerra, Conjunto Marecha Rondon, Henrique Jorge, José Bonifácio, São Cristóvão, Bonsucesso, Parangaba, Alto da Balança, Panamericano, Mucuripe, Relampinho, Àgua Fria, Conjunto Alvorada (Seis Bocas), Cidade 2.000, Aerolândia, Pirambu, Japão, Lagamar, Floresta, Conjunto Professor José Walter. Exatamente que grandeza de renda utilizar para a classificação de uma área como de baixa renda é ponto sujeito a inúmeras interpretações. No caso de Fortaleza como em Salvador - admitiu-se um máximo teórico de seis salários mínimos de renda familiar auferido pelos residentes de determinado espaço habitado, para dizer se esse bairro incluía-se ou não no âmbito do estudo. A questão é que se ignorava a renda real de cada área de Fortaleza, recorrendo-se então, para a demarcação visada, ao auxílio de pesquisadores da universidade do CETREDE e a técnicos da AUMEF. Além disso, pôde-se consultar o material do CETREDE, II Curso de Planejamento de Recursos Humanos, Análise da situação sócio-econômica da população de baixa renda em Fortaleza (Fortaleza, mar. 1977, mimeo)

5. A população de baixa renda de Fortaleza, no entendimento antes proposto, representaria cerca de $60 \%$ da população total da cidade, o que daria 784 mil indivíduos ou 145 mil domicílios em Fortaleza, em 1978

6. Clóvis Cavalcanti e Renato Duarte, obra citada, quadro 2

7. Idem, p.38.

8. Idem, ibidem.

9. Idem, p.40

10. Idem, ibidem.

11. Idem, p.42.

12. Ver, por exemplo, S.V. Sethuraman, The urban informal sector: concept, measurement and policy, International Labour Re view, vol. 114, n: 1 (jul.-ago. 1976)

13. Clóvis Cavalcanti e Renato Duarte, obra citada, p.43

14. Idem, p.48

15. Idem, p.67.

16. Cf. idem, p.61

17. Clóvis Cavalcanti e Renato Duarte, A procura de espaco na economia urbana: o setor informal de Fortaleza (Recife. FUNDAJ. SUDENE-MTb, 1980), p. 129.

18. Clóvis Cavalcanti e Renato Duarte, O setor informal de Salvador, obra citada, p.61.

19. Taxa de câmbio usada: Cr\$ 18,047/dólar (média de 1978, in Banco Mundial, Brazil: human resources special report (Washington, out. 1979), currency equivalents)

20. Apud Banco Mundial, 1979 World Banks Atlas (Washington,

21. Clóvis Cavalcanti e Renato Duarte, A procura de espaço... obra citada, cap. IV, especialmente p.129.

22. Note-se que a análise aqui é por pessoa ativa, e não por pessoa simplesmente ou por familia.

23. Conforme Clóvis Cavalcanti e Renato Duarte, O setor informal de Salvador..., obra citada p.54.

24. Exclui-se de discussão, no caso, a condição de aposentado. 
Quadro 18 Distribuicão da renda por pessoa ativa, por classe de renda pessoal e por tipo de ocupação principal
- junho/1978

(porcentagens)

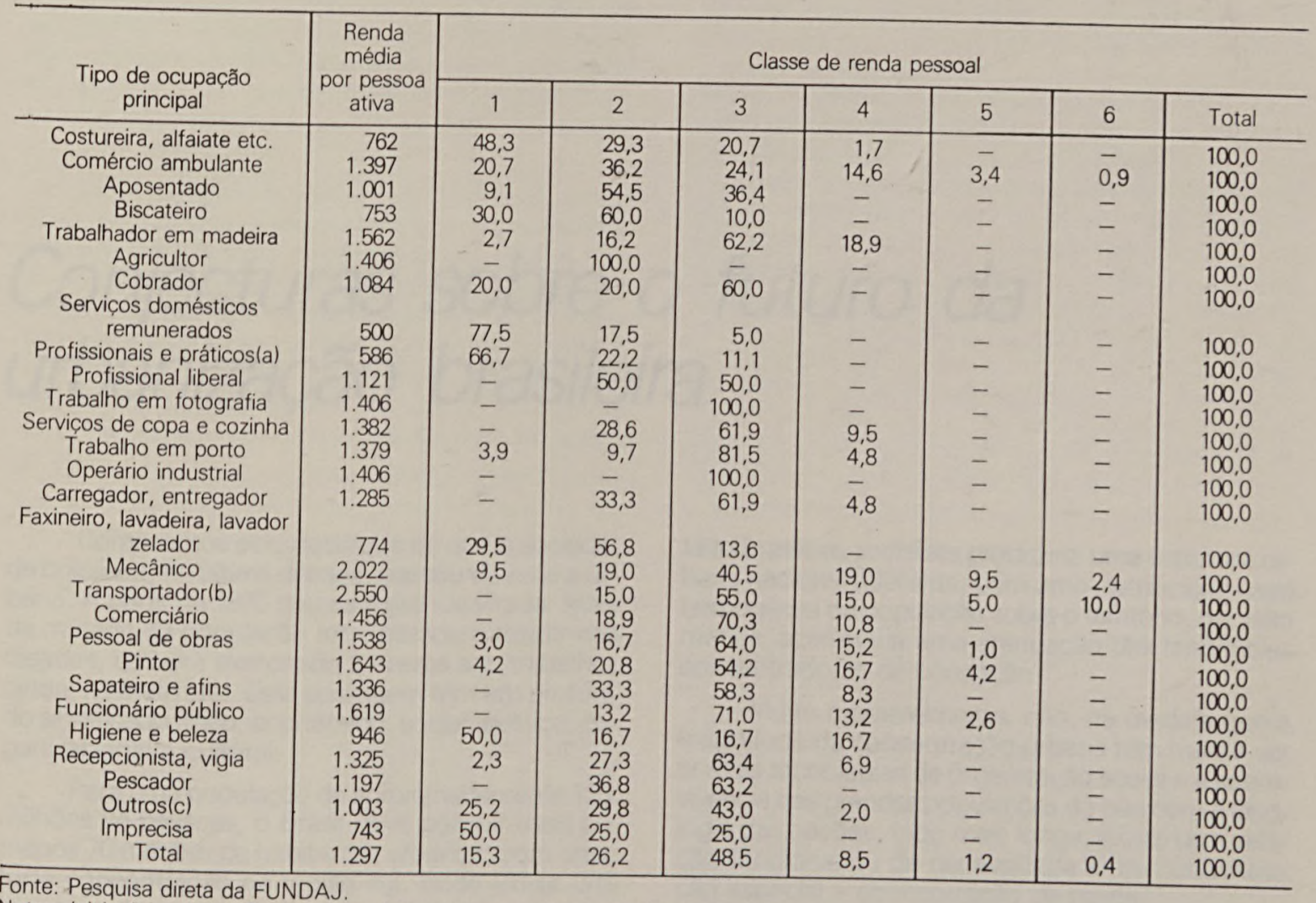

Notas: (a) Inclui enfermeiro, professor, laboratorista, profissionais de nivel médio.

(a) Inclui motorista de táxi, de ônibus, carroceiro etc.

(b) Inclui trabalho em mais de uma atividade, simultaneamente, sem que possa precisar a mais importante. 
